\title{
WINGED FRUITS OF RUTACEOUS AFFINITY FROM THE EOCENE OF WESTERN NORTH AMERICA
}

We dedicate this article to the memory of our inspirational friend and colleague Professor Zlatko Kvaček (1937 - 2020).

\author{
STEVEN R. MANCHESTER ${ }^{1, *}$, KORY A. DISNEY ${ }^{1}$, KASEY K. PHAM $^{1}$
}

${ }^{1}$ Florida Museum of Natural History, Dickinson Hall 1659 Museum Road, Gainesville, Florida 32611-7800, USA; e-mail: steven@ufl.edu. * corresponding

Manchester, S. R., Disney, K. A., Pham, K. K. (2020): Winged fruits of rutaceous affinity from the Eocene of western North America. - Fossil Imprint, 76(2): 211-216, Praha. ISSN 2533-4050 (print), ISSN 2533-4069 (on-line).

\begin{abstract}
A new kind of fin-winged fruit is recognized from lacustrine shales of the early Eocene Tepee Trail Formation of northwestern Wyoming and from the middle Eocene Clarno Formation of central Oregon, USA. The fruits are obovate with five thick lateral wings, borne on a thick pedicel and bearing scars of hypogynous perianth and disk. The fruit surface is covered with small circular dots interpreted as glands. This combination of characters leads us to infer affinities with the Rutaceae, although no identical modern genus is known. We establish the new genus and species, Quinquala obovata.
\end{abstract}

Key words: winged fruits, Tertiary, Wyoming, Oregon, Clarno Formation, Tepee Trail Formation

Received: January 1, 2020 | Accepted: July 28, 2020 | Issued: December 30, 2020

\section{Introduction}

Winged fruits are commonly found as fossils in ancient lake deposits, recovered by splitting shales that also contain fossil leaf remains. Those of familiar genera such as Acer L. (Wolfe and Tanai 1987, Zhu and Manchester 2020), Ailanthus DESF. (Hably 2001, Corbett and Manchester 2004)

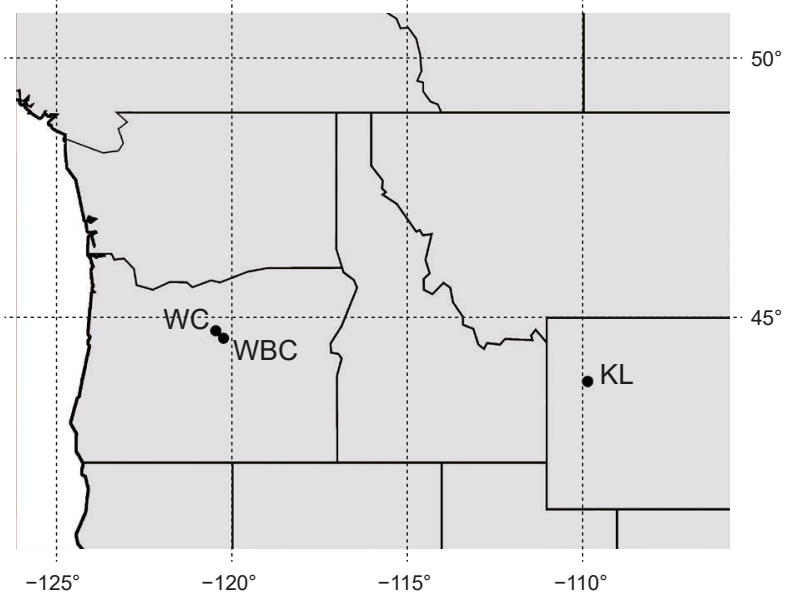

Text-fig. 1. Distribution map for Quinquala obovata gen. et sp. nov. showing the Kisinger Lakes (KL) sites of the Tepee Trail Formation in Wyoming and Clarno Formation localities in Oregon - West Branch Creek (WBC) and White Cliffs (WC). and Ulmus L. (Manchester 1989, Denk and Dillhoff 2005) are readily recognizable due to morphological similarities with living relatives. However, others representing extinct genera can be more difficult to identify due to lack of obvious synapomorphies and/or a novel combination of characters.

Here we describe a new kind of fin-winged fruit found in the Eocene of Wyoming and Oregon and infer its affinity with the Rutaceae Juss. The species is particularly common in the Kisinger Lakes flora from southeast of Yellowstone National Park in northwestern Wyoming, and is also known by rare specimens from lacustrine deposits of the Eocene Clarno Formation in north central Oregon, USA.

\section{Materials and methods}

Most of the fruits were collected along with fossil leaves of various ferns and angiosperms from the early Eocene Kisinger Lakes flora, which is well known on the basis of fossil leaves and pollen (MacGinitie 1974). The shales yielding the Kisinger Lakes flora are correlated with the Tepee Trail Formation (MacGinitie 1974). The specimens were collected along with other reproductive structures and leaves during the summers of 2013 and 2014 and are deposited in the palaeobotanical collection of the Florida Museum of Natural History, University of Florida, Gainesville, FL, USA (UF). Three additional specimens were collected from the Eocene Clarno Formation in Oregon: two from West Branch 

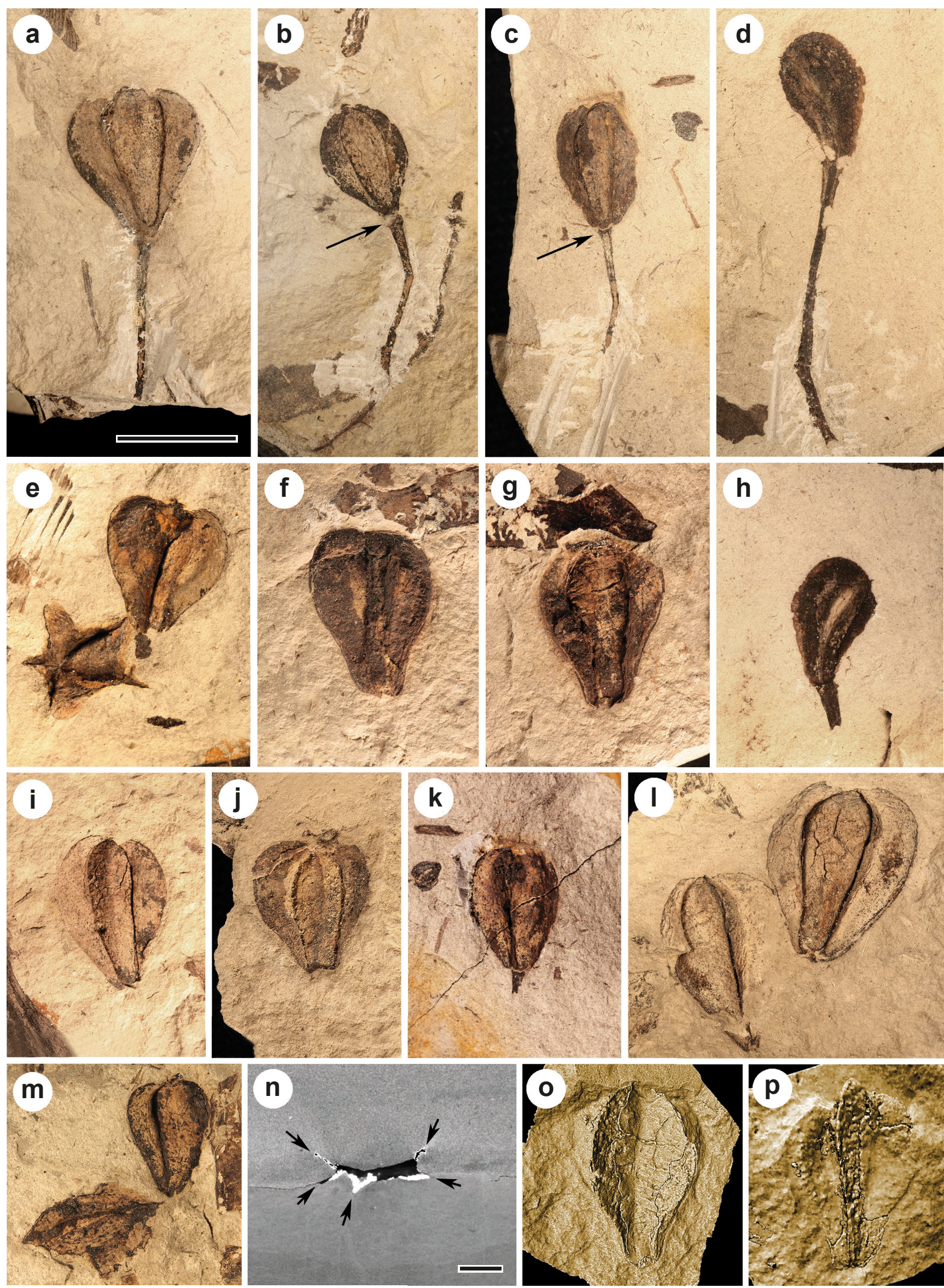

Text-fig. 2. Quinquala obovata gen. et sp. nov., fruits from Kisinger Lakes flora, Wyoming. a: Lateral view of fruit on long pedicel. Note the two lateral wings and pair of longitudinal grooves representing wings extending into the matrix. UF 19376-60038. b: Lateral view of fruit on long, bent pedicel. Note the perianth scar at the base of the fruit (arrow). UF 19376-60023a. c: Lateral view of fruit on long, slightly bent pedicel. Note the pair of longitudinal grooves representing wings extending into the matrix, and 
Creek (UF localities 229 and 230) and one from White Cliffs in the Cherry Creek drainage (UF locality 262).

Specimens were photographed using a pair of LED desk lamps adjusted for low oblique lighting and a Canon Rebel XSi camera with a $60 \mathrm{~mm}$ macro lens. A few specimens were x-rayed with a GE Phoenix V|tome|xm240 micro-CT Scanner at the Nanoscale Research Center, University of Florida, using a Tungsten reflection target, with a voltage of $110 \mathrm{kV}$ and current of $340 \mu \mathrm{A}$ with 1,900 projections over $360^{\circ}$ yielding a voxel size of $38 \mu \mathrm{m}$. The resulting datasets from the micro-CT scans were processed using VG Studio Max (Volume Graphics, Inc., Heidelberg, Germany), Avizo 9 light (FEI, Hillsboro, Oregon, USA), and Meshlab (http:// meshlab.sourceforge.net/; Cignoni et al. 2008) to provide surface renderings and digital sections.

New names of fossil plants are registered in the Plant Fossil Names Registry, which is hosted and operated by the National Museum, Prague for the International Organisation of Palaeobotany (IOP), each with a unique PFN number.

\section{Systematic palaeobotany}

\section{Genus Quinquala Manchester et Disney gen. nov.}

Ty p e. Quinquala obovata MANChester et Disney sp. nov.

Plant Fossil Names Registry Number. PFN001527 (for new genus).

Ety mology. Quinque Latin for five + ala Latin for wing.

D i a $\mathrm{g}$ o s is. As for the species.

Quinquala obovata MANChester et Disney sp. nov. Text-figs 2, 3a-g, i, j, 4

H o lo ty p e. UF 19376-60038 (Text-fig. 2a) housed in Florida Museum of Natural History, Gainesville, USA.

Paratypes. UF 19376-60023a (Text-fig. 2b), UF 19374-60339 (Text-fig. 2c), UF 19376-60050 (Text-fig. 2d), UF 19374-61756 (Text-fig. 2e), UF 19376-60067 (Textfig. 2f, p), UF 19376-60069 (Text-figs 2i, 3e), UF 1937660072 (Text-fig. 2j), UF 19376-60062 (Text-figs 2l, 3f), UF 19374-60403 (Text-fig. 2m), UF 19376-60023b (Textfig. 3a), UF 19376-60023c (Text-fig. 3b), UF 262-17690
(Text-fig. 3c, g), UF 229-53091 (Text-fig. 3d) housed in Florida Museum of Natural History, Gainesville, USA.

Plant Fossil Names Registry Number. PFN001528 (for new species).

Et y m ol ogy. The epithet, obovata refers to the fruit shape.

Type locality. Kisinger Lakes, northwestern Wyoming, USA(UF 19376: N $43^{\circ} 42.056^{\prime}$, W $109^{\circ} 52.918^{\prime}$ ).

Type horizon and age. Tepee Trail Formation, Eocene.

Additional localities. Kisinger Lakes (UF 19374: N 43 42' 01.9", W 109 52' 44.9"; UF 19375: $\mathrm{N} 43^{\circ} 42^{\prime}$ 03.0", W $109^{\circ}$ 52' 53.3"), West Branch Creek, northcentral Oregon, USA (UF 229: N 44 34' 53.40", $\mathrm{W} 120^{\circ} 15^{\prime}$ 57.31"; UF 230: $\mathrm{N} 44^{\circ} 35^{\prime}$ 25.31", W $120^{\circ} 15^{\prime}$ 27.83"; Eocene Clarno Formation), White Cliffs, northcentral Oregon (UF 262: N 44 44.302', W $120^{\circ} 28.376^{\prime}$; Eocene Clarno Formation).

Diagnosis. Fruits single, obovate, 1.1-1.7 times longer than wide. Fruit apex rounded, without a stylar protrusion. Base cuneate and rounded, margins entire. Locular area oblanceolate. Five thick longitudinal wings, veins obscure. Wing and fruit body dotted with circular glands. Fruit borne on pedicel with prominent perianth scar at the junction of pedicel and fruit base. Narrow disk scar located immediately below the perianth scar.

D e s c r i p t i o n. Fruits single, obovate, 9-15 mm long and $6-11 \mathrm{~mm}$ wide with a length/width ratio of 1.1-1.7, avg. 1.4. Fruit apex rounded, without a stylar protrusion. Base cuneate and rounded, margins entire. Locular area oblanceolate. Five thick longitudinal wings, veins obscure. Wing and fruit body dotted with circular glands 80-110 $\mu \mathrm{m}$, avg. $100 \mu \mathrm{m}$ diameter. Fruit borne on pedicel 10-13 mm long and $0.6-1.3 \mathrm{~mm}$ thick, with prominent perianth scar at the junction of pedicel and fruit base. Narrow disk scar located immediately below the perianth scar.

\section{Discussion}

Quinquala fruits are readily recognized by their obovate shape, and consistently five-winged configuration, as depicted in Text-fig. 4. All five wings are visible in transversely compressed specimens (Text-fig. 2e), and

the perianth scar at the base of the fruit (arrow). UF 19374-60339. d: Lateral view of narrower fruit on long, bent pedicel. UF 1937660050. e: Lateral and transverse view of two fruits. Transverse view displays all five wings. UF 19374-61756. f: Lateral view of fruit displaying two lateral wings and one longitudinal groove of a wing extending into the matrix. UF 19376-60067. g: Lateral view of counterpart to (f) displaying the same two lateral wings plus two longitudinal grooves of wings extending into the matrix. UF 1937660067'. h: Lateral view of counterpart to (d). UF 19376-60050'. i: Lateral view of fruit displaying two longitudinal grooves of wings extending into the matrix. Note the cracking in the centre and glandular dots on the two lateral wings. UF 19376-60069. j: Lateral view of fruit displaying two lateral wings and two longitudinal grooves of wings extending into the matrix. UF 19376-60072. k: Lateral view of counterpart to (c) displaying one longitudinal groove of a wing extending into the matrix. UF 19374-60339'. I: Lateral view of two fruits, both displaying two longitudinal grooves of wings extending into the matrix. Fruit on right displays glandular dots and cracking in the centre. Enlarged view of dots and cracks shown in Text-fig. 3f. UF 19376-60062. m: Lateral view of two fruits, both displaying two lateral wings and longitudinal grooves of wings extending into the matrix. UF 19374-60403. n: Digital cross section of (f) and (g) from micro-CT scan data. Note the presence of all five wings (arrows). 0 : Surface rendering of (g) from micro-CT scan data. Note the pair of wings extending from the surface. p: Surface rendering of (f) from micro-CT scan data. Note the one wing extending from the surface. Scale bar in $a=1 \mathrm{~cm}$, applies also to $b-m$ and $0-p$. Scale bar in $\mathbf{n}=1 \mathrm{~mm}$. 

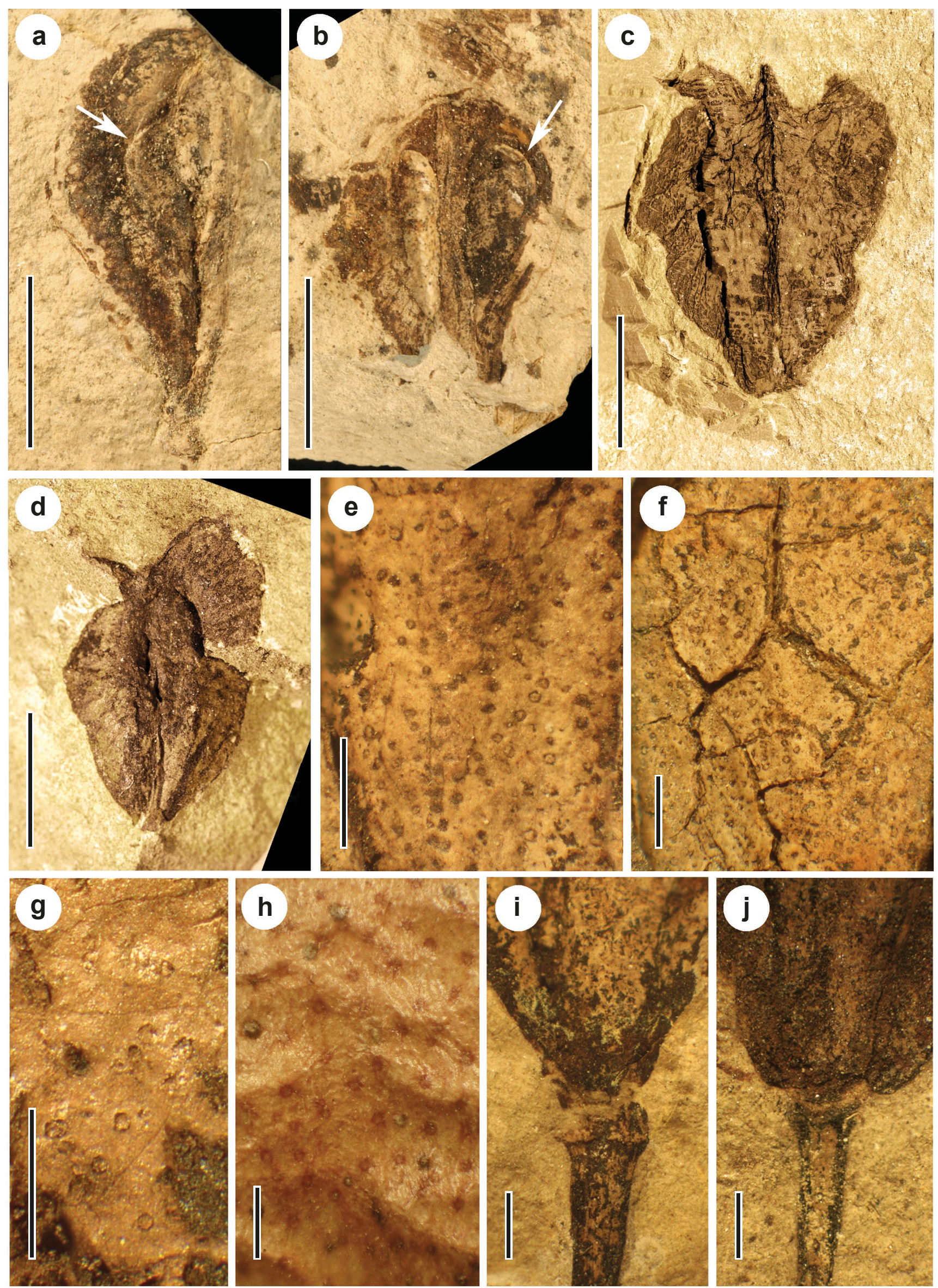

Text-fig. 3. a-g, i, j: Quinquala obovata gen. et sp. nov., fruits from Wyoming and Oregon. a, b: Kisinger Lakes flora, Wyoming. a: Enlarged lateral view of split wing displaying venation along outer edge. Note the seed present in the locular area (arrow). UF 19376-60023b. b: Enlarged lateral view of split wing containing seeds within the locular area (arrow). UF 19376-60023c. c: Lateral view of fruit from White Cliffs, Oregon. UF 262-17690. d: Lateral view of fruit from West Branch Creek, Oregon. UF $229-53091$. 


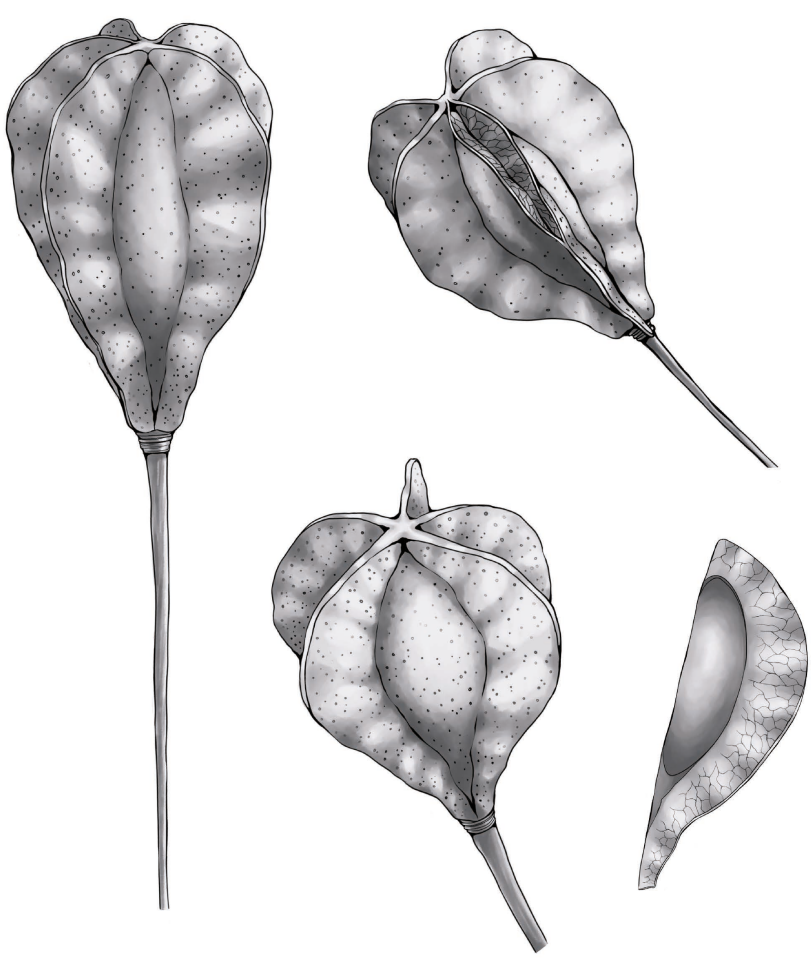

Text-fig. 4. Reconstruction of Quinquala obovata fruits; artwork by K. K. Pham.

can also be inferred by counting the longitudinal grooves extending into the matrix in laterally compressed specimens (e.g., Text-fig. 2c, k). They are also seen by X-ray (Text-fig. $2 n-p)$. The surface of the fruit, when cleared of adhering carbon, is seen to be covered with dots that we interpret to represent circular glands (e.g., Text-figs 2i, 3e). These are visible in the specimens from Oregon as well as those from Wyoming. We were unable to distinguish veins on the wings of intact fruits possibly because vasculature was well embedded within the relatively thick wing tissue.

Most specimens are preserved as whole fruits, suggesting that they were not schizocarpic. However, two specimens appear to be fragments from fruits that had split along the wings (Text-fig. 3a, b). These valves show the outline of an elliptical seed in each locule and reveal a finely reticulate venation. Whether these fragments were naturally shed or were torn is uncertain. The fruits might have been capsular, opening apically, but we have not seen any specimens that show this. The pedicels are $0.6-2 \mathrm{~mm}$ thick and ca. 10-13 $\mathrm{mm}$ long (Text-fig. 2a-d). A kink or scar in the stalk of some specimens suggests a branched infructescence (Text-fig. 2bd). The few specimens with intact pedicel show a swelling at the junction of the pedicel and fruit base, bearing the scars of a thick perianth and an underlying narrow circular disc (Text-fig. 3i, j). This position of the perianth indicates that the fruits developed from superior ovaries.
The combination of five-winged fruits and a hypogynous perianth can occur in various Eudicot families, such as Achariaceae HARMS, Malvaceae Juss., Rutaceae and Zygophyllaceae R.BR. (Manchester and O'Leary 2010). In the Achariaceae, only Grandidiera JAUB. of tropical Africa has 4-6 winged fruits somewhat similar to our fossil. However, the wings in Grandidiera have more prominent venation, are not fixed at five, and a floral disk is not seen. The Malvaceae and Rutaceae include fruits commonly of five carpels and have hypogynous perianth and floral disk.

There is a superficial resemblance to fruits of the zygophyllaceous genus Guaiacum L. (e.g., Manchester and O'Leary 2010: fig. 19e). Both can have 5-winged fruits with similar size and obovate shape, a stout pedicel, and a thick scar at the junction of fruit base and pedicel attributable to a hypogynous perianth. However, Guaiacum fruits are septicidally dehiscent capsules that open along slits between adjacent wings to release the seeds. This is unlike Quinquala fruits, which appear to be either indehiscent or loculicidally dehiscent with the planes of separation bisecting the wings.

The dots on the surface of some of the fruits resemble the circular glands found in fruits and other organs of Rutaceae (Kubitzki et al. 2010). Fruits of Rutaceae are derived from flowers with a hypogynous perianth and commonly have five carpels. A thickened area at the fruit-pedicel junction is also present in the Rutaceae. We conclude that the best fit for these fruits is with the family Rutaceae. This family is well represented in the fossil record based on seeds of the Toddalieae Benth. et HooK.F. going back to the Eocene (Tiffney 1980, Gregor 1989, Collinson et al. 2012). A leaf of Citrus L. was reported from the Miocene of SW China (Xie et al. 2013) and fruits of Ptelea L. have been confirmed from the Miocene of western North America (Call and Dilcher 1995). The extinct genus, Chaneya Yu F.WANG et Manchester, known from distinctive fruits with prominent persistent calyces and five apocarpous carpels from the Eocene and Miocene of Asia, Eocene of North America and Neogene of Europe has also been assigned to Rutaceae based on the morphological characters and presence of circular glands on the calyx and disk (Teodoridis and Kvaček 2005).

Quinquala is common at the Kisinger Lakes localities we collected, but it is exceedingly rare in the Clarno Formation of Oregon, with one specimen each from two West Branch Creek localities (UF loc. 229, 230) and one from a Cherry Creek locality (White Cliffs, UF loc. 262). Despite rarity in the Clarno Formation, its presence there confirms a biogeographic linkage between Eocene floras of central Oregon and northwestern Wyoming. Some other taxa shared between these sites include Lygodium kaulfussii HeEr, Cedrelospermum SAPORTA, Ceratophyllum L., Deviacer Manchester, Macginitiea J.A.Wolfe et WeHr in Manchester (1986) and Iodes Blume (Allen et al. 2015). It is noteworthy that we have not observed any Quinquala fruits

e: Enlarged view of glandular dots from Text-fig. 2i. UF 19376-60069. f: Enlarged view of cracking and glandular dots from Textfig. 2l. UF 19376-60062. g: Enlarged view of glandular dots on (c). h: Glandular dots on the surface of a modern fruit of Ptelea trifoliata. Bloomington, Indiana, UF mod ref coll. 1766. i: Enlarged view of perianth scar at the junction of pedicel and base of fruit from Text-fig. 2b. UF 19374-60339. j: Enlarged view of perianth scar at the junction of pedicel and base of fruit from Text-fig. 2c. UF 19376-60023a. Scale bars $=5 \mathrm{~mm}$ for a-d. Scale bars $=1 \mathrm{~mm}$ for $\mathrm{e}-\mathrm{j}$. 
from other Eocene sites to the South in Wyoming, Utah and Colorado despite other floristic similarities.

\section{Acknowledgements}

We thank Terry Lott, Sanping Xie, Sarah E. Allen, Jianhua Jin, Xinxin Feng, and Xiaoyan Liu for assistance in field work at the Kisinger Lakes localities. Terry Lott helped with proof reading of the manuscript. Tau $\mathrm{Su}$ and Edoardo Martinetto provided helpful review comments. This work was funded in part by NSF grant DEB-1404895 to SRM.

\section{References}

Allen, S. E., Stull, G. W., Manchester, S. R. (2015): Icacinaceae from the Eocene of western North America. American Journal of Botany, 102(5): 725-744. https://doi.org/10.3732/ajb.1400550

Call, V. B., Dilcher, D. L. (1995): Fossil Ptelea samaras (Rutaceae) in North America. - American Journal of Botany, 82(8): 1069-1073. https://doi.org/10.1002/j.1537-2197.1995.tb11572.x

Cignoni, P., Callieri, M., Corsini, M., Dellepiane, F., Ganovelli, F., Ranzuglia, G. (2008): MeshLab: an open-source mesh processing tool. - In: Scarano, V., De Chiara, R., Erra, U. (eds), Sixth Eurographics Italian Chapter Conference. Eurographics Association, Geneva, pp. 129-136.

Corbett, S. L., Manchester, S. R. (2004): Phytogeography and fossil history of Ailanthus (Simaroubaceae). International Journal of Plant Sciences, 165(4): 671-690. https://doi.org/10.1086/386378

Collinson, M. E., Manchester, S. R., Wilde, V. (2012): Fossil fruits and seeds of the Middle Eocene Messel biota, Germany. - Abhandlungen der Senckenberg Gesellschaft für Naturforschung, 570: 1-250.

Denk, T., Dillhoff, R. M. (2005): Ulmus leaves and fruits from the Early-Middle Eocene of northwestern North America: systematics and implications for character evolution within Ulmaceae. - Botany, 83(12): 1663-1681. https://doi.org/10.1139/b05-122

Gregor, H. J. (1989): Aspects of the fossil record and phylogeny of the family Rutaceae (Zanthoxyleae, Toddalioideae). - In: Ehrendorfer, F. (ed.), Woody plants - evolution and distribution since the Tertiary. Springer, Vienna, pp. 251-265. https://doi.org/10.1007/978-3-7091-3972-1_13

Hably, L. (2001): Fruits and leaves of Ailanthus Desf. from the Tertiary of Hungary. - Acta Palaeobotanica, 41: 207-219.

Kubitzki, K., Kallunki, J. A., Duretto, M., Wilson, P. G. (2010): Rutaceae. - In: Kubitzki, K. (ed.), The Families and Genera of Vascular Plants. Vol. 10. Springer, Berlin, pp. 276-356.

https://doi.org/10.1007/978-3-642-14397-7_16

MacGinitie, H. D. (1974): An Early Middle Eocene flora from the Yellowstone-Absaroka volcanic province, Northwestern Wind River Basin, Wyoming. - University of California Publications in Geological Sciences, 108: $1-103$.

Manchester, S. R. (1986): Vegetative and reproductive morphology of an extinct plane tree (Platanaceae) from the Eocene of western North America. - Botanical Gazette, 147(2): 200-226. https://doi.org/10.1086/337587

Manchester, S. R. (1989): Systematics and fossil history of the Ulmaceae. - In: Crane, P. R., Blackmore, S. (eds), Evolution, Systematics, and fossil history of the Hamamelidae, Volume 2: 'Higher' Hamamelidae (Systematics Association Special Volume no. 40B). Clarendon Press, Oxford, pp. 221-252.

Manchester, S. R., O’Leary, E. L. (2010): Phylogenetic distribution and identification of fin-winged fruits. - The Botanical Review, 76(1): 1-82. https://doi.org/10.1007/s12229-010-9041-0

Teodoridis, V., Kvaček, Z. (2005): The extinct genus Chaneya Wang et Manchester in the Tertiary of Europe - a revision of Porana-like fruit remains from Öhningen and Bohemia. - Review of Palaeobotany and Palynology, 134: 85-103. https://doi.org/10.1016/j.revpalbo.2004.12.002

Tiffney, B. H. (1980): Fruits and seeds of the Brandon Lignite, V. Rutaceae. - Journal of the Arnold Arboretum, 61(1): 1-40. https://doi.org/10.2307/2806671

Wolfe, J. A., Tanai, T. (1987): Systematics, phylogeny, and distribution of Acer (maples) in the Cenozoic of western North America. - Journal of the Faculty of Science, Hokkaido University Series 4, Geology and Mineralogy, 22: 1-246.

Xie Sanping, Manchester, S. R., Liu Kenan, Wang Yunfeng, Sun Bainian (2013): Citrus linczangensis sp. n., a leaf fossil of Rutaceae from the late Miocene of Yunnan, China. - International Journal of Plant Sciences, 174: 1201-1207. https://doi.org/10.1086/671796

Zhu Hai, Manchester, S. (2020): Red and Silver Maples in the Neogene of western North America: Fossil leaves and samaras of Acer Section Rubra. - International Journal of Plant Sciences, 181: 542-556. https://doi.org/10.1086/707106 